Bangladesh J. Bot. 42(2): 343-348, 2013 (December)

\title{
RESPONSE OF INTERCROPS AND NUTRIENT MANAGEMENT ON THE PERFORMANCE OF TOBACCO BASED INTERCROPPING SYSTEM AND ASSESSMENT OF SYSTEM SUSTAINABILITY
}

\author{
Anil Kumar Singh*, KA Singh, RC Bharati and Naresh Chandra \\ ICAR Research Complex for Eastern Region, Patna -800 014, India
}

Key words: Tobacco, Intercrops, Nutrient management, Soil fertility status, Economic feasibility, Rajmas, Potato, Garlic

\begin{abstract}
Intercropping of tobacco with garlic produced the highest total (2292 kg/ha) and first grade (1256 kg/ha) cured leaves of tobacco. In the recommended dose of respective intercrops $75 \%$ produced total and first grade cured tobacco leaves compared to 100 per cent of the recommended dose. Tobacco quality was also influenced with nutrient management. Puckering and maturity scores did not impaired up to 50 per cent application of nutrients to intercrops. Among the intercrops garlic gave the highest economic yield (1.18 t/ha) over three years on the basis of monetary gain. The highest net return (Rs 47,948 / ha) and cost benefit ratio (1:1.78) was achieved under tobacco + garlic intercropping system. Nutrient supplied at 75 percent of recommended dose provided net return (Rs 45551/ ha) and cost benefit ratio (1:1.81) equivalent to 100 per cent of recommended doses. Soil fertility was either maintained or improved due to intercropping intervention in comparison to cultivating tobacco sole.
\end{abstract}

\section{Introduction}

Tobacco (Nicotiana tobacum L.) is an important commercial crop which is traded for its quality leaves and quoted as golden leaf in the world market. India is one of the largest producer and exporter of tobacco in the world. Total tobacco production in India is about 700 million kilograms annually and the market's already worth a massive US \$5 billion (Singh 2010). It contains several alkolids including nicotine which can be used in a variety of ways including medical and agricultural pest management. It can be grown under wide range of climatic and soil conditions which play a crucial role in Indian economy in general and Bihar in particular (Singh et al. 2000). Tobacco especially chewing type is a remunerative rabi cash crop of irrigated uplands of Bihar. Majority of (about 80\%) tobacco growers/farmers fall under small and marginal capacity with land holding size of less than one hectare (Singh, 2010). With the improved crop management practices and availability of high yielding, short duration, photo- and thermoinsensitive varieties of different crops provides ample scope for experimenting with several crops combinations to develop tobacco based cropping systems to scale up the economic status of tobacco growers of Bihar State. To improve their income from tobacco field without compromising production and quality of main crop i.e. tobacco, intercrops possessing short canopy, able to provide competition free environment as well as having high market value are the important parameters for selection of intercrops. Garlic (Allium sativum L.), potato (Solanum tuberosum L.) and common bean (Phaseolus vulgaris L.) were the crops which by and large fit well in the yardsticks.

\section{Materials and Methods}

Present study was undertaken to find out optimum nutrient management (fertility level) for these highly remunerative intercrop components without affecting the yield and quality of base crop tobacco and its long-term sustainability with respect to soil fertility and economic feasibility

*Author for correspondence: <anil.icarpat@gmail.com> 
of under Bihar condition to uplift the economy of tobacco grower to and boost economic status of poor farmers.

An experiment was conducted during rabi seasons at the Crop Research Programme, $\left(25.98^{\circ}\right.$ $\mathrm{N}$ Latitude, $85.67^{\circ} \mathrm{E}$ Longitude), Pusa, Bihar. The soil quality of the filed field has been published elsewhere (Singh, 2010). The factorial experiment was conducted under Randomized Block Design (RBD) replicated thrice. The gross plot size was $6.0 \times 5.4 \mathrm{~m}$ and net plot $4.0 \times 3.6 \mathrm{~m}$. Weather parameters including rainfall were almost favorable during all three years. Since crop was taken during winter with assured irrigation, role of rainfall was minimum. The experiment was planned with two factors i.e. (1) intercrops and (2) fertility levels. Three intercrops, i.e. garlic, common bean and potato were taken in the widely spaced base/main crop i.e. tobacco in additive series. In this cropping system main crop having 100 per cent plant population while intercropped may or may not up to the 100 per cent of its normal population. In case of nutrient management, fertilizer dose was calculated for intercrops. Two rows of each intercrops were sown/planted in between alternate tobacco rows 10 - 15 days after planting of tobacco. Five fertility levels @ 100, 75, 50, 25 and $0 \%$ of recommended dose were applied to intercrops whereas for tobacco (main crops) were provided with $100 \%$ of recommended fertilizer. Fifty per cent of total N of $250 \mathrm{~kg} / \mathrm{ha}$ was applied through mustard cake and rest through urea, single super phosphate and muriate of potash were used as source of $\mathrm{P}$ and $\mathrm{K}$, respectively, to supply $70 \mathrm{~kg}$ each per hectare 10 days before planting of tobacco. Recommended doses of nitrogen, phosphorus and potassium ( $\mathrm{N}: \mathrm{P}$ : K) for each of the intercrops i.e. garlic; $100: 60: 80$, common bean, $60: 60: 40$ and potato 120 : $60: 80 \mathrm{~kg} / \mathrm{ha}$ were applied as basal application. The tested varieties were Pusa Tobacco-76 (PT76), Yamuna Safed, PDR-14 and Kufri Chandamukhee for tobacco, garlic, common bean and potato, respectively. Healthy tobacco seedlings of 45-day-old were transplanted in the experimental plots at $90 \times 90 \mathrm{~cm}$ spacing during the first week of October in all the three years. Tobacco plants were topped at bottom stage retrieving 14 leaves per plant and piercing by a needle on the top at $2-3 \mathrm{~cm}$ deep for breaking the apical dominance. Physical leaf quality parameters such as spangling, puckering and maturity were evaluated on 0 - 10 scales. Data on total and first grade leaf yield were subjected to statistical analysis. To know the economic sustainability of developed technology economics of the different treatments were worked out on the basis of added input and output. Soil physical and chemical properties were also studied to know the fertility dynamics and impacts of intercropping system on it and its sustainability. The soil samples were analyzed following the procedure described by AOAC (1980). Regular analysis of variance was performed for each trait for all three seasons and the combined (pooled) analysis over seasons after testing error variance homogeneity was carried out according to the procedure outlined by Gomez and Gomez (1984), using the MSTATC version 2.1 (Michigan State University, USA) statistical package design. Significant differences between the treatments were compared with the critical difference at $( \pm 5 \%)$ probability by LSD.

\section{Results and Discussion}

Growth and development of tobacco is by and large influenced with various intercrops though its magnitude differs. Number of curable leaves per plant and leaf area is the important yield attributes. Results revealed that number of curable leaves recorded maximum (13.4) when tobacco was intercropped with garlic and at par with potato (13.2) and significantly higher than common bean. Fertility level has also significant influence on number of curable leaves. Application of 75 per cent of recommended dose produced at par with of 100 and 50 percent of recommended dose (Table 1). The highest leaf area (2.08) ( $\left.\mathrm{m}^{2} / \mathrm{plant}\right)$ of tobacco was recorded in the plots in which common bean was grown as intercrop (Table 1). Application of 75 per cent of recommended doses to intercrops produces the highest LAI (2.14) which was at par with 100 per cent and 
significantly superior over 50 per cent of recommended dose. Similar results were also reported by Singh et al. (2000), Kasturi et al. (2004), Kumaresan et al. (2008), and Singh et al. (1998).

Tobacco intercropped with garlic produced the highest $(2292 \mathrm{~kg} / \mathrm{ha})$ total cured leaf and (1256 kg/ha) first grade leaf and produces at par with rajmas. Corresponding minimum total cured leaf, first grade leaf, was recorded when potato was taken as intercrop (Table 2). Tobacco intercropped with garlic increased total cured and first grade leaf yields over potato and the increase was to the extent of 6.9 and 7.9 per cent, respectively. Significant increase in total cured and first grade leaf yield was also reported by Singh et al. (1998), Singh et al. (2000), Singh (2010) and Kumaresan et al. (2008). Beneficial effect of intercropping has also been reported by Lakshminarayana (1996), Kasturi et al. (2004) and Singh (2010). The interaction between intercrops and with years was significant for total cured and first grade leaf yields. Among the fertility levels, application of 75 per cent at par with 100 per cent of recommended dose for intercrops recorded significant increase in yield of total cured and first grade leaf over others tested fertility levels viz. 50, 25 and 0 per cent (Table 2). The high yield at high fertility level i.e. 100 per cent level were also reported by Reddy et al. (2006), Kasturi et al. (2004), Singh et al. (2000) and Singh (2010).

Table 1. Effects of intercrops and fertility levels on growth and development of tobacco.

\begin{tabular}{|c|c|c|c|c|c|c|c|c|}
\hline \multirow{3}{*}{ Treatment } & \multicolumn{8}{|c|}{ Growth parameters } \\
\hline & \multicolumn{4}{|c|}{ No. of curable leaves/plant } & \multicolumn{4}{|c|}{ Leaf area (m²/plant) } \\
\hline & $\begin{array}{l}\text { First } \\
\text { year }\end{array}$ & $\begin{array}{l}\text { Second } \\
\text { year }\end{array}$ & $\begin{array}{l}\text { Third } \\
\text { year }\end{array}$ & $\begin{array}{l}\text { Pooled } \\
\text { mean }\end{array}$ & $\begin{array}{l}\text { First } \\
\text { year }\end{array}$ & $\begin{array}{l}\text { Second } \\
\text { year }\end{array}$ & $\begin{array}{l}\text { Third } \\
\text { year }\end{array}$ & $\begin{array}{l}\text { Polled } \\
\text { mean }\end{array}$ \\
\hline \multicolumn{9}{|l|}{ Intercrops } \\
\hline Garlic & 13.3 & 13.5 & 13.3 & 13.4 & 2.26 & 1.73 & 2.16 & 2.05 \\
\hline Common bean & 13.0 & 13.3 & 13.3 & 13.2 & 2.30 & 1.74 & 2.21 & 2.08 \\
\hline Potato & 13.4 & 13.1 & 13.2 & 13.2 & 2.28 & 1.67 & 2.11 & 2.02 \\
\hline S.Em \pm & 0.14 & 0.13 & 0.07 & 0.07 & 0.06 & 0.04 & 0.02 & 0.02 \\
\hline CD (p 0.05) & NS & NS & NS & 0.19 & NS & NS & 0.05 & 0.05 \\
\hline \multicolumn{9}{|c|}{ Fertility level (as \% of RD) } \\
\hline 100 & 13.4 & 13.2 & 13.3 & 13.3 & 2.32 & 1.73 & 2.27 & 2.11 \\
\hline 75 & 13.4 & 13.3 & 13.4 & 13.4 & 2.31 & 1.84 & 2.27 & 2.14 \\
\hline 50 & 13.3 & 13.4 & 13.2 & 13.3 & 2.22 & 1.75 & 2.17 & 2.05 \\
\hline 25 & 13.2 & 13.1 & 13.3 & 13.2 & 2.32 & 1.63 & 2.09 & 2.01 \\
\hline 0 & 12.9 & 13.6 & 13.2 & 13.2 & 2.23 & 1.16 & 2.03 & 1.96 \\
\hline S.E. & 0.18 & 0.17 & 0.09 & 0.06 & 0.78 & 0.5 & 0.02 & 0.03 \\
\hline $\mathrm{CD}(\mathrm{p} 0.5)$ & NS & NS & NS & 0.17 & NS & 0.15 & 0.06 & 0.09 \\
\hline
\end{tabular}

Since tobacco is one of the few crops cultivated for its quality leaves having good test and aroma as well, hence quality parameter is also recorded. Physical leaf quality parameters of tobacco were significantly influenced by both the treatment i.e. intercrops and fertility gradients. Spangling (8.14) and puckering (8.19) scores were recorded significantly higher when tobacco was intercropped with rajmas. It may be attributed to the nature of rajmas crop being legume. However, in case of maturity score maximum (8.43) was noticed when garlic was taken as intercrop. Moreover the differences between other two crops on these quality parameters were non-significant (Table 3). Application of 75 per cent of recommended dose produced similar spangling score as in case of 100 per cent and produced significantly higher score than other tested 


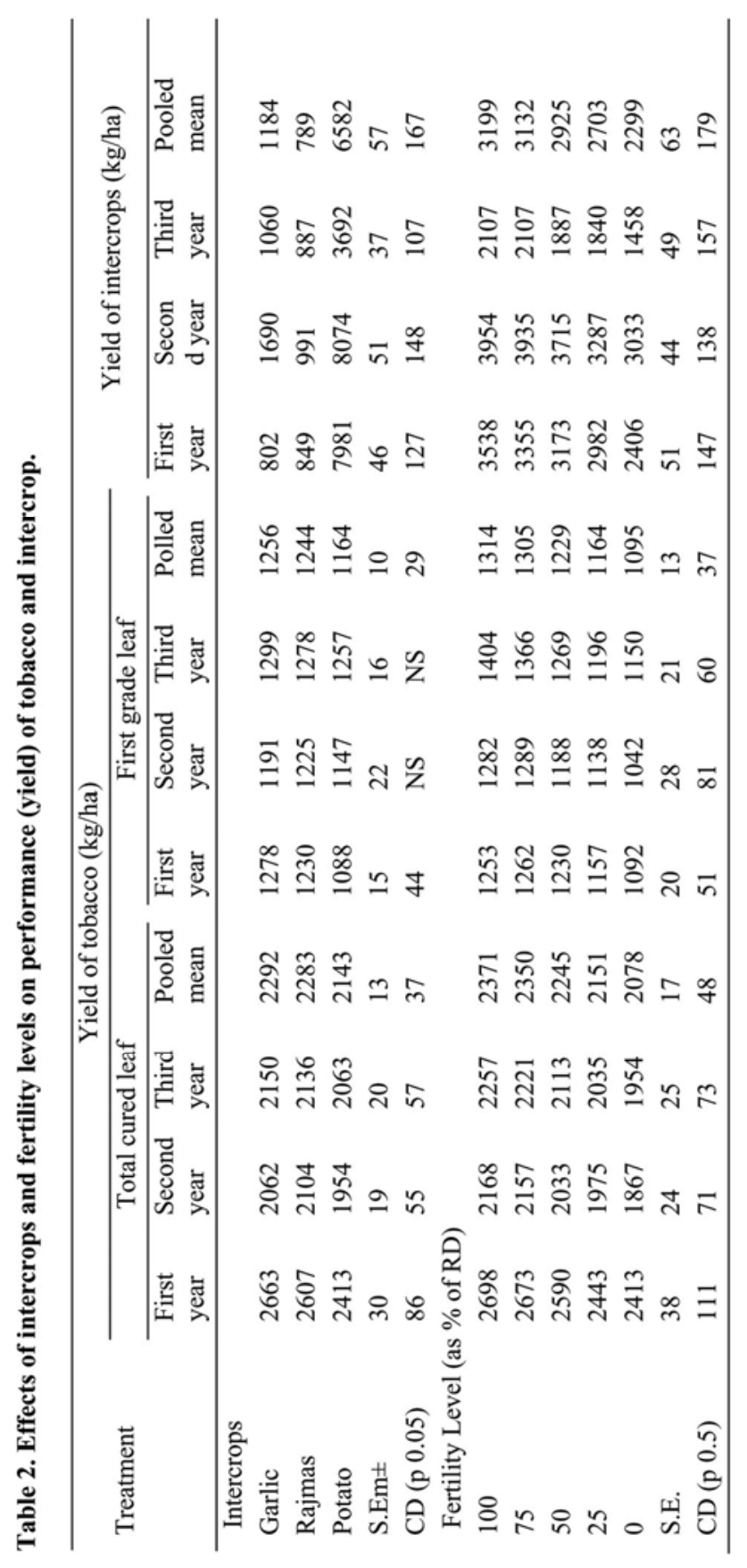


fertility dose. Similar results were also observed in case of puckering scores. Identical maturity score was obtained upto 50 percent dose of recommended fertilizer. Further reduction in dose significantly reduced the maturity score (Singh et al. 2000; Singh 2010; Kumaresan et al. 2008 and Singh et al. 1998).

Table 3. Effects of intercrops and fertility levels on economics of cropping system.

\begin{tabular}{lcccc}
\hline Treatment & $\begin{array}{c}\text { Cost of cultivation } \\
\text { (Rs. /ha) }\end{array}$ & $\begin{array}{c}\text { Gross return } \\
\text { (Rs. /ha) }\end{array}$ & $\begin{array}{c}\text { Net return } \\
\text { (Rs. /ha) }\end{array}$ & C:B ratio \\
\hline A. Intercrops & & & & \\
Garlic & 54982 & 97930 & 42928 & $1: 1.78$ \\
Common bean & 54998 & 95597 & 41581 & $1: 1.74$ \\
Potato & 56762 & 93547 & 36785 & $1: 1.65$ \\
B. Fertility level in intercrop (as \% of RD) & & & \\
100 & 56923 & 102831 & 45908 & $1: 1.81$ \\
75 & 56276 & 101827 & 45551 & $1: 1.81$ \\
50 & 55551 & 96854 & 41302 & $1: 1.74$ \\
25 & 54889 & 91759 & 36870 & $1: 1.67$ \\
0 & 54264 & 86822 & 32558 & $1: 1.60$ \\
\hline
\end{tabular}

In all the three years of experimentation, intercropping with garlic and common bean gave higher yield of tobacco leaf than intercropping with potato but in the third year difference between common bean and potato intercrops on tobacco leaf yield was not significant. Performance of individual intercrop fluctuates considerably. Hence, pooled data is more relevant for interpretation of the results. Data on mean yields of intercrops showed that garlic gave $1184 \mathrm{~kg} / \mathrm{ha}$, common bean $789 \mathrm{~kg} / \mathrm{ha}$ and potato $6582 \mathrm{~kg} / \mathrm{ha}$ over three years. Based on biomass it seems that potato might be a good intercrop but the real picture is based on economic value of the produce of individual intercrop. In case of fertility levels, application of 100 per cent of the recommended dose to the intercrops produced at par with 75 percent of the fertility level. Further, reduction in fertility levels significantly and drastically reduces the production of intercrop (Table 2). Similar conclusions were also drawn by Lakshminarayana (1996), Kasturi et al. (2004), Singh (2010) and Singh et al. (2000).

Economic analysis of treatment revealed that in the case of intercropping system highest net return of (Rs. 47,948/ha was recorded under tobacco intercropped with garlic followed by tobacco intercropped with Rajmas (Rs. 41,581/ha). The highest cost benefit ratio (1: 1.78) was for garlic whereas corresponding lower value was noticed in case of potato. The difference between the two intercropping system was Rs. 1367/ha. Among the fertility levels, application of 100 or 75 percent of the recommended dose for intercrops gave only a marginal difference of Rs. 357/ha (Table 3). However, further reduction of fertility levels prove terminal and reduced yield radically. The highest cost benefit ratio $(1: 1.81)$ was recorded with application of 100 or 75 per cent of the recommended dose and lowest $(1: 1.60)$ with no application of fertilizer, Kumaresan et al. (2008), Lakshminarayana (1996), Singh (2010) and Singh et al. (1998).

\section{Acknowledgements}

Assistance received by the central laboratory facility for soil analysis at ICAR Research Complex for Eastern Region Patna, India is duly acknowledged. 


\section{References}

AOAC 1980. Official methods of analysis of the association official analytical chemist. $13^{\text {th }}$ Edn. AOAC, Washington DC, USA.

Gomez KA and Gomez AA 1984. Statistical procedures for agricultural research. John Wiley \& Sons Inc., Singapore 2nd Edn. pp. 574.

Kasturi KS, Krishna Reddy SV and Krishnamurthy V 2004. Effect of spacing, levels of nitrogen and topping on yield and quality of irrigated natu tobacco (Nicotiana tabacum L.) grown in Alfisols of Andhra Pradesh. Indian J Agron. 49: 124 -127.

Kumaresan M, Kumar P, Harish V, Krishnamurthy and Athinarayanan R 2008. Economic viability and residual soil-nutrient status in chewing tobacco (Nicotiana tabacum) - based cropping system. Indian $\mathrm{J}$ Agron. 53: 273-278.

Lakshminarayana R 1996. Tobacco. In: 50 Years of Crop Science Research in India, Paroda RS and Chadha KL (Eds), pp. 401-415. ICAR, New Delhi.

Reddy PRS, Singh KD and Jain KC 2006. Achievements in tobacco research. Central Tobacco Research Institute, Rajahmundry Andhra Pradesh. pp. 77.

Singh AK 2010. Tobacco. Satish Serial Publishing House, New Delhi. pp. 447.

Singh KD, Tripathi SN and Pandey AK 1998. Studies on feasibility and economic viability of tobacco based intercropping system in Bihar. Tob. Res. 24: 70-76.

Singh KD, Krishnamurthy V and Pandey AK 2000. Studies on soil fertility management in tobacco based sequential cropping system under irrigated and rainfed conditions of Bihar. Tob. Res. 26: 28-36.

Singh RD, Dey A and Singh A K 2011. Vision - 2030. ICAR Research Complex of Eastern Region, Patna. p. 26. 